KEMAS 15 (2) (2019) 206-212
Jttp://journal.unnes.ac.id/nju/index.php/kemas

\title{
Traditional Softball Games Effective Modified for Improving Nutritional Status and Physical Fitness in Elementary School Children
}

\author{
M. Choiroel Anwar ${ }^{1 凶}$, Irwan Budiono², Hermawan Pamot $^{3}$ \\ ${ }^{1}$ Poltekkes Kemenkes Semarang \\ ${ }^{2}$ Study of Nutrition Program, Sport Science Faculty, Universitas Negeri Semarang \\ ${ }^{3}$ Study of Physical Education Health and Recreation, Sport Science Faculty, Universitas Negeri Semarang
}

\section{Article Info \\ Article History: \\ Submitted October 2019 \\ Accepted November 2019 \\ Published November 2019 \\ Keywords: \\ Traditional Children \\ Games, Nutrition \\ Status, Physical Fitness \\ DOI \\ https://doi.org/10.15294/ \\ kemas.v15i2.21524}

\begin{abstract}
Traditional children's games at school have the potential to decrease the prevalence of obesity which tends to increase. Modifications and standardization of the game are needed so that the game can be implemented. The research objective is to develop a modified softball game model and test its effectiveness for improving nutritional status and physical fitness level of elementary school students. The development research design was used to produce the modified softball game model. Field trials of 27 elementary school fifth grade students were carried out with a one group before and after intervention design. The effectiveness of the model was assessed by changes in $\mathrm{Z}$ score of body mass index and physical fitness level before and after the intervention. The results of this research prove that the modified softball game model is valid and relevant to the physical education review. Application of the modified softball game model also proved effective in improving the nutritional status and physical fitness level of elementary school students. In the context of overcoming the problem of over nutrition in school-age children, it is recommended that schools and related stake holders implement the modified softball game model consistently.
\end{abstract}

\section{Introduction}

One of the important health issues to be on the agenda of health promotion for elementary school children is the problem of over nutrition (overweight and obesity). Several studies show the high problem of over nutrition in elementary school age children both in developed and developing countries. Haug et al (2009) in a study conducted 10 years ago published that the prevalence of obesity in developed countries reached $28.8 \%$, while in developing countries it reached $7.6 \%$. Research on the prevalence of obesity in China also shows a similar result. Zhang's research shows the prevalence of overweight and obesity in China reaches $12.5 \%$ and $15.7 \%$ (Andegiorgish et al., 2012). Until now, there are no data on overweight and obesity in school-age children collected nationally. However, it is suspected that the prevalence of overweight and obesity is starting to increase (Kemenkes, 2019).

The condition of over nutrition in childhood according to some studies has the potential to continue at a later age. This means that over nutrition that occurs in childhood will be at risk of continuing into adulthood (Haug et al., 2009; Williams et al., 2015) weight, eating patterns, physical activity and sedentary behaviours were obtained from nationally representative samples in 41 countries $(n=204,534$. The potential for the problem of over nutrition in children to adulthood can be seen from the tendency to increase overweight and obesity in the last decade. 
Data on Basic Health Research (Riskesdas) in 2018 shows a tendency to the prevalence increase of overweight and obesity in the age group $>18$ years in Indonesia. The prevalence of overwieght increased from $8.6 \%$ in 2007 to $11.5 \%$ in 2013 , then to $13.6 \%$ in 2018 . Similarly, the prevalence of obesity increased successively from $2007,2008,2018$ by $10,5 \%, 14.8 \%$, and 21.8\% (Kemenkes, 2019).

Several previous studies have revealed the cause of over nutrition, which involves genetic, environmental, and behavioral variables. The pathogenesis of overweight is greater energy intake than energy outtake. The biggest cause of obesity and over nutrition in school-age children is the lack of physical activity on the one hand, and on the other hand is the consumption of excessive food (Tichá et al., 2018; Zhang et al., 2019). Elementary school age children in Semarang City showed that $20.5 \%$ of students had a negative energy balance. This means that energy outtake is lower than the energy intake (Budiono, 2013).

Energy imbalance that appears from the data above needs a solution to the problem in the form of developing a variety of physical activities in elementary school children. Characteristics of elementary school-aged children are eager to be involved in a game, therefore it is necessary to develop traditional games as part of the learning process in schoolage children. Adoption of several types of traditional children's games in the learning process significantly contributes to improving fitness and improving energy balance in children.

There are many types of traditional children's games in various parts of Indonesia. Some have the potential to be implemented in schools. Traditional children's games that were once popular include Lusiama softball. However, to be implemented in intra and extracurricular activities in schools it is necessary to modify and standardize. The purpose is to adjust to the limitations of time, place, facilities and school infrastructure.

Based on this background, the purpose of this research is to produce a modified Lusiama softball game model. Furthermore, the model was tested to improve the nutritional status and physical fitness level of elementary school students.

\section{Method}

This development research was carried out to produce a modified model of traditional children's games that were standardized as an alternative intervention program for the problem of over nutrition and physical fitness of elementary school students. Standardized game models mean that children's games are equipped with game guides to be implemented in various schools with the same procedures. The traditional game developed in this research is softball.

The phases in the development of game model consisted of 3 stages, namely preliminary studies, model development, and field trials. A preliminary study was conducted to select a variety of traditional children's games to be developed. Model development was carried out by making draft modifications to traditional children's games, testing the relevance of game models with the objective of developing models, and conducting expert validation of the developed game models. The field trial phase was implementing the model to elementary school students. This phase is carried out to evaluate the effectiveness of the model in improving the nutritional status and physical fitness level of students.

Game Model Implementation

The one group before and after intervention design was implemented to test the effectiveness of softball game model implementation to nutrition status improvement and student physical fitness. The model implementation design can be seen on image 1.

The subjects in the user test were 28 elementary school physical education teachers in the city of Semarang. The subject of the model validation test were 3 physical education experts from doctoral qualified academics in the field of physical education. The subjects for the field trial were all grade 5 students of Sekaran 2 Primary School, Gunungpati Subdistrict, Semarang city, as many as 27 children.

The instrument used in determining the nutritional status of students is the Seca brand stamped scale to measure body weight, and microtois to measure height. Nutritional status was assessed by $\mathrm{z}$ body mass index 


\begin{tabular}{|l|l|l|l|}
\hline $\begin{array}{l}\text { Measurement I : } \\
\text { - Putrition status (BMI) }\end{array}$ & $\begin{array}{l}\text { Group A (SD Patemon 1) : Castle Game } \\
\text { Group B (SD Sekaran 2) : Softball Game }\end{array}$ & $\begin{array}{l}\text { Measurement II : } \\
\text { (BMI) }\end{array}$ \\
\hline \hline Before Intervention & $\begin{array}{l}\text { Intervention period : 12 times of the game with 30 } \\
\text { minutes duration per time and 3 times per week for 1 } \\
\text { month. }\end{array}$ & After Intervention \\
\hline
\end{tabular}

Figure 1. Intervention Design

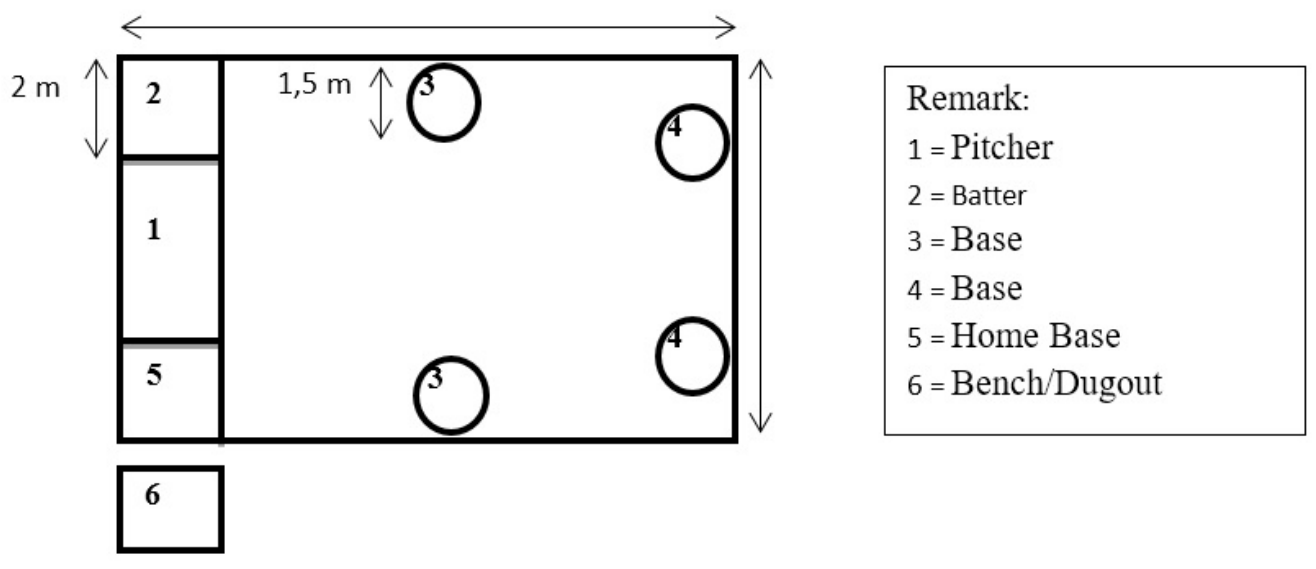

Figure 2. Modification of Softball game area

score according to age (Kemenkes, 2011). Measurement of physical fitness level was carried out in accordance with Indonesian physical fitness test guidelines for elementary school students (Widiastuti, 2015).

\section{Result and Discussion}

Modification of softball game is applied in the game area, rules, and procedures for the game. The area of conventional baseball games is hexagonal in shape. The shape of the field has several obstacles, namely the need for a large field so that it is difficult to implement in schools with limited field area. To optimize the utilization of the field area owned by the school, the baseball field is modified in the form of a rectangle, as in the following figure 2.

Modified rules and procedures for the softball game in principle is intended to increase the participation of all students in the game. The game is designed to be done by all students both male and female, and can be done by students with limited mobility. It's model was designed so that all players get the same opportunity to hit, throw, catch the ball, and run. Modification of time is also done so that the duration of the game is more measurable.

Before the modification was implemented, a user test and validation were first done by a physical education expert. User test is a user perceptional assessment of the relevance of the model to physical education review. Table 1 shows the user test results and expert validation of the softball game model in terms of physical education aspects.

The results of user ratings as shown in table 1 indicates that the modified softball game model is relevant to the physical education review. An assessment of 16 aspects of the physical education review showed all $>75 \%$. This means that the model developed is relevant to the physical education review. Likewise, the results of the expert validity test showed that the Aikens's $\mathrm{V}$ coefficient value for each item was $>0.92$. This means that the model developed has good content validity.

The effectiveness of the game models developed in improving the nutritional status and physical fitness of students

Field trials to determine the effectiveness of the game model on improving 
Table 1. Relevance of Modified Softball Game Model from Physical Education Overview based on User Perceptional Evaluation

\begin{tabular}{|c|c|c|c|c|c|c|c|}
\hline \multirow{2}{*}{ No } & \multirow{2}{*}{ Aspect assessed } & \multicolumn{4}{|c|}{$\begin{array}{l}\text { User Validation of elementary school physical } \\
\text { education teacher }\end{array}$} & \multicolumn{2}{|c|}{$\begin{array}{l}\text { Expert Validation of } \\
\text { physical education Doctor }\end{array}$} \\
\hline & & $\begin{array}{l}\text { Counted } \\
\text { Score }\end{array}$ & $\begin{array}{l}\text { Criterion } \\
\text { Score }\end{array}$ & Value & Conclussion & $\begin{array}{l}\text { Coefficient } \\
\text { value of } \\
\text { Aiken's V }\end{array}$ & Conclussion \\
\hline 1 & Basic Competence accordance & 110 & 112 & 98,21 & Relevant & 1,00 & Valid \\
\hline 2 & Clear game regulation & 107 & 112 & 95,54 & Relevant & 1,00 & Valid \\
\hline 3 & $\begin{array}{l}\text { Accuracy in choosing the form / model of } \\
\text { the game for students }\end{array}$ & 111 & 112 & 99,1 & Relevant & 1,00 & Valid \\
\hline 4 & Suitability of tools and facilities used & 108 & 112 & 96,43 & Relevant & 1,00 & Valid \\
\hline 5 & Increase student's pulse & 107 & 112 & 95,54 & Relevant & 1,00 & Valid \\
\hline 6 & Easy in tools provision & 110 & 112 & 98,21 & Relevant & 1,00 & Valid \\
\hline 7 & Easy in field preparation & 107 & 112 & 95,54 & Relevant & 0,92 & Valid \\
\hline 8 & $\begin{array}{l}\text { The ease of form or model of the game for } \\
\text { students to play }\end{array}$ & 111 & 112 & 99,11 & Relevant & 1,00 & Valid \\
\hline 9 & $\begin{array}{l}\text { Match the shape or model of the game with } \\
\text { the characteristics of students }\end{array}$ & 108 & 112 & 96,43 & Relevant & 1,00 & Valid \\
\hline 10 & Encourage students' physical development & 107 & 112 & 95,54 & Relevant & 1,00 & Valid \\
\hline 11 & $\begin{array}{l}\text { Encourage the development of student } \\
\text { interest in Physical Education and } 108 \\
\text { locomotor movements }\end{array}$ & 111 & 112 & 99,11 & Relevant & 1,00 & Valid \\
\hline 12 & $\begin{array}{l}\text { Encourage the development of student } \\
\text { skills in locomotor base motion }\end{array}$ & 108 & 112 & 96,43 & Relevant & 1,00 & Valid \\
\hline 13 & $\begin{array}{l}\text { Can be played by skilled and unskilled } \\
\text { students }\end{array}$ & 107 & 112 & 95,54 & Relevant & 1,00 & Valid \\
\hline 14 & Can be played by male and female students & 110 & 112 & 98,21 & Relevant & 1,00 & Valid \\
\hline 15 & Encourage students to actively move & 107 & 112 & 95,54 & Relevant & 1,00 & Valid \\
\hline 16 & $\begin{array}{l}\text { Safe to apply in learning locomotor basic } \\
\text { motion games }\end{array}$ & 111 & 112 & 99,11 & Relevant & 1,00 & Valid \\
\hline \multicolumn{2}{|c|}{ Average } & 108,75 & 112 & 97.09 & Relevant & - & - \\
\hline
\end{tabular}

Source : Primary Data, 2019

Remark :

Counted score $=$ The total score of assessment (range score 1-4) per item from all respondents

Criterion score $=$ The ideal total score if all respondents answered with the highest score (4) for each item

Value $=$ total score $/$ criterion score $\mathrm{x} 100 \%$

The acceptance limit of Aiken's $\mathrm{V}$ coefficient with raters 3 experts is 0.92 
Table 2. Characteristic of Research Subjects Gender and Age

\begin{tabular}{llll}
\hline Characteristics & Category & Frequence & Percentage \\
\hline Gender & Male & 17 & 63,0 \\
& Female & 10 & 37,0 \\
& Total & 27 & 100,0 \\
Age & 10 years & 10 & 37,0 \\
& 11 years & 16 & 59,3 \\
& 12 years & 1 & 3,7 \\
& Total & 27 & 100,0 \\
\hline
\end{tabular}

Source : Primary Data, 2019

Table 3. Nutritional Status and Physical Fitness Level of Students Before and After Intervention

\begin{tabular}{lllll}
\hline \multirow{2}{*}{ Rsearch Variable } & & Before Intervention & After intervention & \\
& & $\mathrm{n}(\%)$ or $\mathrm{M} \pm \mathrm{SD}$ & $\mathrm{n}(\%)$ or $\mathrm{M} \pm \mathrm{SD}$ & $\mathrm{p}$ value \\
\hline Z Score IMT / U & & $-0,6200 \pm 2,6148$ & $-0,7300 \pm 2,309$ & $0,0001^{\mathrm{a}}$ \\
Nutrition Status & Normal & $18(66,7 \%)$ & $19(70,4 \%)$ & $0,0001^{\mathrm{b}}$ \\
Category & Overweight & $1(3,7 \%)$ & $1(3,7 \%)$ & \\
& Obese & $8(29,6 \%)$ & $7(25,9 \%)$ & \\
Score TKJI & Total & $27(100,0 \%)$ & $27(100,0 \%)$ & $0,0001^{\text {a }}$ \\
Student Physical & & $19 \pm 2,433$ & $22 \pm 2,306$ & $0,0001^{\text {b }}$ \\
Fitness Level & Poor & $1(3,7 \%)$ & $1(3,7 \%)$ & \\
& Average & $4(14,8 \%)$ & $2(7,4 \%)$ & \\
& Good & $19(70,4 \%)$ & $9(33,3 \%)$ & \\
& Excellent & $3(11,1 \%)$ & $15(55,6 \%)$ & \\
& Total & $27(100,0 \%)$ & $27(100,0 \%)$ & \\
\hline
\end{tabular}

Source : Primary Data, 2019

aPearson Correlation

${ }^{b}$ Wilcoxon Signed Ranks Test

nutritional status and physical fitness level of students were conducted on 27 students of SD Negeri Sekaran 2 in Gunungpati, Semarang City. The characteristics of the research subjects are shown in table 2.

Table 2 shows that the gender of most subjects were male (63\%). The research subjects were grade 5 students with most were 11 years old (59.3\%). Furthermore, the data in table 3 shows the changes in nutritional status and fitness level of students after 12 physical exercise interventions were given with a baseball game model.

Based on the results of nutritional status assessment as shown in table 3, the prevalence of over nutrition that occurred in research subjects was high. The prevalence of over nutrition before the intervention was $29.6 \%$, and $25.9 \%$ after the intervention. The prevalence of obesity shows that the problem of over nutrition has become a global problem. This means that the same problems occur both in rural and urban areas, and occur in both developed and developing countries (Andegiorgish et al., 2012; Colley et al., 2019; Garrido-Miguel et al., 2019; Tichá et al., 2018).

Related to the prevalence of obesity which tends to increase, the results of this research indicate the hope of overcoming obesity through the application of traditional games for school children. The data in table 3 shows an increase in the median $\mathrm{Z}$ body mass index score according to age after administration of the intervention. Statistically 
this change was significant $(p=0.0001)$. An interesting research finding is the decrease in subjects with obesity category from $29.6 \%$ to $25.9 \%$ after the application of baseball games. The results confirm previous research findings about the effect of increased physical activity on decreasing body mass index in children (GaticaDomínguez et al., 2018; Maury-Sintjago et al., 2019; Mora-Gonzalez et al., 2019).

The results of this research as shown in table 3 also indicates a significant difference in physical fitness test score variables before and after the intervention $(p=0.0001)$. The data shows a decrease in the percentage of students with a good physical fitness level from $70.4 \%$ to $33.3 \%$ after the intervention. The decrease is because there were 10 students who originally had a good physical fitness level category turned out to be very good after participating in the intervention program. The results are relevant to previous research findings that mentioned interventions increasing physical activity in school-age children are effective in increasing physical fitness and preventing over nutrition problems in students (García-Hermoso, Alonso-Martinez, Ramírez-Vélez, \& Izquierdo, 2019; Gatica-Domínguez et al., 2018; Lee, Ho, Keung, \& Kwong, 2014).

Modified softball game model in this research proved to be effective in improving nutritional status and physical fitness levels of students. Implementation with a frequency of 3 times per week with a duration of 30 minutes if applied consistently by schools can be an alternative to overcoming the problem of over nutrition. Physiologically it is due to increased activity energy expenditure (AEE). AEE is one component of total energy expenditure (TEE). Some other TEE components are resting energy expenditure (REE), thermic effect of food, and energy for growth. Of the various TEE components, AEE is a component that can be used as a parameter for the success of interventions for over nutrition in school-age children (Ball et al., 2001).

The results of this research answer the questions of previous researchers about what intervention programs are effective for solving the problem of over nutrition in school-age children. The modified softball game of this research allowed all students to be actively involved in the game, therefore the target of increasing AEE could be achieved more effectively (Ball et al., 2001; Molnar \& Livingstone, 2000) heart rate studies using low heart rate threshold and doubly labelled water studies indicate relatively high levels of activity in children. The three national surveys on large representative samples reported that $60 \%$ to $70 \%$ of all children were involved in sufficient physical activity according to various definitions. Heart rate studies demonstrate that children generally perform short bouts of moderate to vigorous activities and seldom participate in long-sustained vigorous activities. They also proved that children perform large volumes of activity in the lower heart rate zones. It is generally accepted that boys are more active than girls and physical activity declines by age (peak around 13 to 14 years of age. Some important aspects that need to be considered in choosing a program to increase physical activity in school-age children are 1) the intervention must be a fun game, 2) provide opportunities for all students to participate actively, 3) game can be done by boys and girls, and can be played by children with limited mobility, 4) the facilities and infrastructure of the game are easily accessible and obtained by the school.

\section{Conclussion}

Rating of the user to the Softball game model modification shows the average comparison of the calculated score with the criterion score of each user rating items by $97.09 \%$. It can be concluded that the modified softball game model has relevance to the physical education review. Aiken V coefficient values for all items assessed by expert validators are all $>0.92$, meaning that the modified softball game model developed is valid, so it can be used for large scale trials. Based on the results of a large-scale trial, it can be concluded that the implementation of the modified baseball game has been proven to improve the $\mathrm{z}$ score body mass index $(p=0.0001)$ and the student's physical fitness level ( $\mathrm{p}-0.0001)$.

Considering the results of this research, it is recommended that the modified softball game developed can be implemented in elementary schools. The consequent and consistent application of modified game model 
can be a good practice in overcoming the problem of over nutrition in elementary school age children.

Acknowledgments is addressed to the Poltekes Kemenkes Semarang for funding the research, as well as the sekolah dasar Negeri Sekaran 02 Semarang for supporting the research.

\section{References}

Andegiorgish, A. K., Wang, J., Zhang, X., Liu, X., \& Zhu, H., 2012. Prevalence of Overweight, Obesity, and Associated Risk Factors Among School Children and Adolescents in Tianjin, China. European Journal of Pediatrics, 171(4): 697-703.

Ball, E. J., O'Connor, J., Abbott, R., Steinbeck, K. S., Davies, P. S. W., Wishart, C., ... Baur, L. A., 2001. Total Energy Expenditure, Body Fatness, and Physical Activity in Children Aged 6-9 Y. American Journal of Clinical Nutrition, 74(4): 524-528.

Budiono, I., 2013. Pengembangan Model Indeks Pembangunan Gizi. KESMAS - Jurnal Kesehatan Masyarakat, 8(2): 166-175.

Colley, R. C., Clarke, J., Doyon, C. Y., Janssen, I., Lang, J. J., Timmons, B. W., \& Tremblay, M. S., 2019. Trends in Physical Fitness mong Canadian Children and Youth. Statistics Canada, Catalogue, 30(10): 3-13.

García-Hermoso, A., Alonso-Martinez, A. M., Ramírez-Vélez, R., \& Izquierdo, M., 2019. Effects of Exercise Intervention on HealthRelated Physical Fitness and Blood Pressure in Preschool Children: A Systematic Review and Meta-Analysis of Randomized Controlled Trials. Sports Medicine.

Garrido-Miguel, M., Cavero-Redondo, I., ÁlvarezBueno, C., Rodríguez-Artalejo, F., Moreno, L. A., Ruiz, J. R., ... Martínez-Vizcaíno, V., 2019. Prevalence and Trends of Overweight and Obesity in European Children From 1999 to 2016. JAMA Pediatrics, 173(10), e192430.

Gatica-Domínguez, G., Moreno-Saracho, J. E., Cortés, J. D., Henao-Moran, S. A., \& Rivera, J. A., 2018. Condición Física de Escolares tras Intervención Educativa Para Prevenir Obesidad Infantil en Morelos, México. Salud Pública de México, 61(1)

Haug, E., Rasmussen, M., Samdal, O., Iannotti, R., Kelly, C., Borraccino, A., ... Nansel, T., 2009. Overweight in School-aged Children and Its Relationship with Demographic and Lifestyle Factors: Results from the WHO-
Collaborative Health Behaviour in Schoolaged Children (HBSC) Study. International Journal of Public Health, 54(SUPPL. 2).

Kemenkes., 2011. Keputusan Menteri Kesehatan Republik Indonesia Nomor 1995/Menkes/ SK/XII/2010 tentang Standar Antropometri Penilaian Status Gizi. Jakarta: Kementerian Kesehatan RI.

Kemenkes., 2019. Hasil Utama Riset Kesehatan Dasar 2018. Jakarta: Kementerian Kesehatan RI.

Lee, A., Ho, M., Keung, V. M. W., \& Kwong, A. C. M., 2014. Childhood Obesity Management Shifting from Health Care System to School System: Intervention Study of School-Based Weight Management Programme. BMC Public Health, 14(1): 1-10.

Maury-Sintjago, E., Rodríguez-Fernández, A., Parra-Flores, J., \& Garcia, D. E., 2019. Association between Body Mass Index and Functional Fitness of 9- to 10-year-old Chilean Children. American Journal of Human Biology, (July), 1-5.

Molnar, D., \& Livingstone, B., 2000. Physical Activity in Relation to Overweight and Obesity in Children and Aolescents. European Journal of Pediatrics, Supplement, 159(1): 45-55.

Mora-Gonzalez, J., Esteban-Cornejo, I., CadenasSanchez, C., Migueles, J. H., Molina-Garcia, P., Rodriguez-Ayllon, M., ... Ortega, F. B., 2019. Physical Fitness, Physical Activity, and the Executive Function in Children with Overweight and Obesity. Journal of Pediatrics, 208(00): 50-56.e1.

Tichá, L., Regecová, V., Šebeková, K., Sedláková, D., Hamade, J., \& Podracká, L., 2018. Prevalence of Overweight/obesity among 7-year-old Children-WHO Childhood Obesity Surveillance Initiative in Slovakia, Trends and Differences between Selected European Countries. European Journal of Pediatrics, 177(6): 945-953.

Widiastuti., 2015. Tes dan Pengukuran Olahraga. Jakarta: Rajawali Press.

Williams, E. P., Mesidor, M., Winters, K., Dubbert, P. M., \& Wyatt, S. B., 2015. Overweight and Obesity: Prevalence, Consequences, and Causes of a Growing Public Health Problem. Current Obesity Reports, 4(3): 363-370.

Zhang, Y., Liu, S., Li, Y., Li, X., Ren, P., \& Luo, F., 2019. The Relationships Between Weight Status and Physical Fitness Among Chinese Children and Youth. Research Quarterly for Exercise and Sport, 90(2): 113-122. 